\title{
AS ANEMIAS HIPOCRÔMICAS E SEU TRATAMENTO
}

\author{
PEDRO JANNINI
}

Médico Interno da 2,a M. H. Enfermaria do Prof. Rubião Meira. - Assistente do ambulatório de péle e sífilis da Policlínica. Serviço do Dr. H. Cerruti

Dos ramos da ciência médica, que, nestes ultimos decênios, tomaram um grande e decidido surto destaca-se a hematologia. Com efeito, nesse terreno foram de maior vulto as novas aquisições suscetíveis de levar a um conhecimento mais íntimo e profundo do fenómeno da hematopoiese. As novas pesquisas chegaram a determinar resultados práticos de grande alcance, pois um certo numero de moléstias, cujo prognóstico era, outróra, fatal, assumiram agora, à luz dos novos conhecimentos, aspectos mais benignos.

Os novos caminhos abertos pelos pesquisadores sugeriram processos terapêuticos que melhoraram consideravelmente o prognóstico de um sem numero de enfermos cujo mal, outróra, tendia para um fim irremediavelmente fatal. $E^{\prime}$ o que aconteceu, por exemplo, com a anemia perniciosa cuja gravidade foi enormemente atenuada mercê das conclusões da moderna hematologia.

Note-se que dentro de sua órbita, os diversos ramos da hematologia não tomaram, em absoluto, um desenvolvimento uniforme. Em alguns de seus departamentos as pesquisas foram mais intensas e de mais promissores resultados como no caso do estudo dos glóbulos vermelhos, graças à descoberta da patogenía de muitos estados anêmicos.

O nosso fito, no presente trabalho, é fazer ligeiras considerações sobre as anemías de um modo geral e depois discutị a questão do tratamento das anemías hipocrômicas ou ferroprivas.

Conceito do eritrônio: Considerando, particularmente, os eritrocítos, eles teem sua individualidade fisiológica cuja principal função é o transporte de oxigênio aos tecidos. Esses mesmos elementos teem seu ponto de formação nos ninhos de eritroblástos que se acham localisados nos divertículos sinusóides dos orgãos hematopoiéticos, e, na idade adulta, exclusivamente na medúla óssea. Portanto os eritrocítos e seus precursores na medúla óssea poderiam ser considerados como um todo, como um verdadeiro orgão cuja principal função é a de transporte de oxigênio. Pois bem, é a esse conjunto, eritrocítos circulantes no sangue periférico e seus precursores na medúla óssea que Boycotт em 1929 (1) denominou de "erythron" acentuando 
assim essa estreita relação entre o tecido eritroblástico da medúla óssea e os eritrocítos do sangue circulante.

A propria patologia nos confirma essa estreita relação: muitos estados mórbidos, com comprometimento do tecido eritroblástico teem a sua repercussão imediata nos glóbulos vermelhos circulantes. Basta citar os processos infeciosos com inibição da eritropoiese e consequente diminuição dos eritrocitos circulantes; certas afeções que atingem unicamente o contingente eritroblástico como as policitemías, eritremías, etc..

Considerando como um todo, o eritrônio é um orgão muito maior do que o figado. O seu tecido intersticial é, no sangue periférico, o plasma e na medúla óssea são a gordura e as células do retículo.

Assim como existe uma patologia do rim, ou melhor, do nefrônio,, por exemplo, assim tambem poderemos falar de patologia do eritrônio, pois, do mesmo modo que em outros orgãos, o eritrônio póde sofrer um incremento ou uma diminuição de sua função, sef removido em parte e, tambem, póde ser a séde do início de processos mórbidos, como dissémos ha pouco.

O eritrônio difére de outros orgãos como o rim, figado, por exemplo, devido ao fáto de que a obtenção de amostras do mesmo é muito facil, de modo que, em qualquer processo mórbido, poderemos estudá-lo verificando as modificaçốes que nele se passam, procésso esse que não pode ser feito com a mesma facilidade relativamente aos outros orgãos, cuja função poderemos estudar ou saber quasi que, sómente, por meios indirétos.

'Interessante é a comparação feita por Wrtss (2), do eritrônio. Esse autôr comparou. o eritrônio à pele cujas diferentes camadas, (stratum germinativum, mucosum, granulosum, lucidum e corneum) seriam correspondentes aos diferentes estádios por que passa o eritroblàsto até o eritrocíto o qual, do mesmo modo que a camada cornea formada por componente de tecido involuido, seria tambem um elemento involuido mas, fisiológicamente ativo. De fáto, o eritrocíto é uma célula, sinão morta, em vias de degeneração, pois já perdeu o seu componente principal que é o núcleo.

O eritrônio varía quanto ao seu tamanho, de acôrdo com as diferentes idades; ele diminue à medida que a idade avança. $\mathrm{Na}$ criança, a medúla óssea funcionante atinge todos os ossos longos (epífises e diáfises) e ossos chatos do crâneo. Com o correr dos anos ha uma diminuição dessa medúla funcionante (vermelha) que vae se tornando amarela pela transformação das células aí existentes em células adiposas para quando chegar na velhice, mais ou menos 70 anos, ela se transformar em medúla cinzenta. Fato interessante é que essa involução se faz de uma maneira centrípeta (Ponfik e NEumanN (3-4)) e simétricamente em ambos os lados do corpo. De um modo geral, desaparece a médula atíva das epífises dos ossos longos da perna e diáfise dos ossos longos dos membros superiores, desaparecimento 
esse, gradatívo, de modo que aos 15 anos de idade existe, normalmente, medúla atíva sómente nas vértebras, costelas, externo, crâneo, osso inominado e estremidades proximais dos ossos longos dos braços e pernas. E' a esse fenómeno que se dá o nome de "converǵência troncular da hematopoiese".

Quando, por um motivo qualquer, o organismo necessita maior quantidade de eritrocítos do que o normal, a medúla amarela adquire novamente a sua atividade eritropoiética transformando-se em medúla vermelha graças às células reticulares que aí se encontram em estádio potencial e aos divertículos sinusóides vestigiários; é a hiperplasía do eritrônio. O contrario, isto é, a hipoplasía e mesmo a aplasía pode ser verificado.

E' conveniente assinalarmos que consideraremos sómente a parte referente aos glóbulos vermelhos deixando de lado, os brancos (granulocitos, parte dos monocitos), plaquetas, elementos esses que são formados, tambem, pela medúla óssea.

Eritropoiese: Embora, como dissemos ha pouco, na medúla óssea se formem os granulocítos, parte dos monocítos, e os eritrocítos, consideraremos neste trabalho sómente a gênese dos eritrocítos ou eritropoiese por ser o que nos interessa no momento.

Os glóbulos vermelhos são formados em diferentes orgãos no ínicio da vida mas, à medida que a idade avança, certos pontos de formação desses elementos perdem essa função ficando esclusivamente reservada, na idade adulta, para a medúla óssea, no homem.

Convem assinalar que nos outros mamíferos, segundo estudos de ORIA, (51) persistem os eritrônios esplênicos durante toda a vida extra uterina.

No ínicio da vida intra uterina o embrião apresenta 3 camadas: ectoderma, endoderma e mesoderma. Pois bem, já no saco vitelino, no mesoderma especialisado com o nome de angioblasto, umas certas células mesenquimais se diferencíam adquirindo função geradora de células angioblásticas: formam-se verdadeiros ninhos de células constituindo as ilhotas de Wolf, circundadas por essas células que adquiririam carater endotelial e que constituem, posteriormente, o endotélio dos vasos dos orgãos hematopoiéticos; as células que permanecem envoltas por esse endotélio vão dar origem aos elementos vermelhos do sangue. Antes do aparecimento do fígado no embrião, esses elementos vermelhos são constituidos esclusivamente por megaloblastos: é a gênese megaloblástica. Depois, com o aparecimento daquele orgão a gênese megaloblástica é substituida pela eritroblástica que assim permanece durante toda a vida. Entretanto, é sabído que no fígado, durante algum tempo, permanecem vestígios da eritropoiese megaloblástica, vestígios esses transportados pela veia vitelina que vae ter ao fígado nesse período.

Os elementos vermelhos do sangue pois, são formados por dentro desse endotélio caindo logo na circulação - é a gênese intra vas- 
cular em oposição aos elementos brancos (granulocitos, plaquetas, etc.) que são formados por fóra desses capilares e que, por um movimento ameboide atravessam a parede desses mesmos capilares caindo na circulação — é a gênese extra-vascular.

O fígado e o baço desempenham a função eritropoietica até mais ou menos o terceiro mês da vida intra uterina para o primeiro e até o sétimo ao oitavo mês para o segundo; depois, com o aparecimento da função hematopoiética da medúla dos óssos, aqueles orgãos deixam essa função: o fígado deixa de produzir elementos sanguíneos e o baço vae se encarregando, por assim dizer, sómente da produção dos linfocítos. Fica então, como orgão eritropoiético por excelencia, a medúla óssea.

A evolução das células mesenquimais para os eritrocítos, sè faz de uma maneira coordenada passando por diversas etápas e evoluindo sincrônicamente o citoplasma e o núcleo até a célula final-eritrocíto. Para que se processe essa evolução vários fatores interveem, uns, aumentando ou excitando a multiplicação das células primitivas (fatôres excitantes ou cito evolutivos), outros, provocando o amadurecimento do citoplasma e do núcleo (fatôres de maturação). A falta de um dos fatôres de maturação, por exemplo, irá trazer perturbações relativamente ao amadurecimento das células de modo que poderemos observar a falta de paralelismo entre o amadurecimento do citoplasma e do núcleo constituindo o que se chama "anaplasía", fáto esse muito importante porque frequentemente encontramo-lo nas anemías de carência.

Os orgãos, que nos primórdios da vida intra uterina, tinham função eritropoiética, podem, em determinado momento, adquiri-la novamente graças à totipotencialidade das células mesenquimais que aí permanecem. E' o que se nota em muitos estádios patológicos (leucemías, eritremías, etc.) onde verificamos fócos de eritropoiese ou leucopoiese no fígado, baço, rim, etc..

Essas células que possuem tal potencialidade funcional receberam de varios autôres diferentes nomes: no fígado são as chamadas células de Küpfer, células migrantes em repouso (Maximow), clasmatocitos de Ranvier, células adventiciais de Marchand, hemohistioblasto de Ferrata, etc. (5-6). O fáto da presença de nomes diversos é devido a esses autôres terem estudado diferentes setôres do organismo onde essas células adquirem propriedades diferentes de acôrdo com o orgão ou setôr. Entretanto, em conjunto, elas nada mais são que células de um sistema totipotente a que Kyıono e Aschoff deran o nome de "sistema retículo endotelial" (5-6).

Da célula mesenquimal indiferente, totipotente, hemohistioblasto segundo a nomenclatura de FERRATA deriva, precocemente, o hemocitoblasto cuja função, como o próprio nome indíca, é a de produzir unica e exclusivamente as células do sangue. 
Sería de conveniência que fizéssemos agora uma ligeira pausa e considerássemos alguns pontos importantes cuja lembrança sería de muita utilidade para termos sempre em mente as diferentes fases pelas quais passa o progenitôr das hemátias até o seu estádio adulto, etapas essas, cuja nomenclatura, para quem potico leu sobre o assunto sempre trás alguma confusão.

E' de importancia saber-se, em primeiro lugar, que as células vermelhas ou hemátias, acidófilas devido a sua hemoglobina e anucleadas, derivam de elementos cujo citoplasma é basófilo e provído de núcleo. À medida que esses elementos primordiais da série vermelha vão amadurecendo verificam-se modificações no citoplasma e no núcleo, que se fazem de maneira sincrônica, isto é, a evolução do núcleo se processa juntamente com as modificações do citoplasma. O que se verifíca é o seguinte: para o lado do núcleo a cromatina,' que a principio é muito delgada, à medida que vae evoluindo vae se espessando até ser constituida por blocos espessos, grandes, separados por espaços claros para depois confluirem, formando um bloco único menor, constituindo a picnose nuclear e finalmente ser eliminado do citoplasma por cariorexis, cariolise ou expulsão total.

As modificações que se passam no citoplasma, . dizem respeito quasi que exclusivamente à hemoglobinisação do mesmo, de modo que a célula, inicialmente basófila, passa a ser acidófila. Pois bem, a ásincronía entre a evolução do núcleo e do citoplasma, por exemplo a presença de uma célula cujo núcleo é quasi picnotico e o citoplasma ainda conserva-se basófilo, constitue a chamada anaplasía cujo conhecimento é importante principalmente quando se estudam as anemías de carência.

Como a nomenclatura das diferentes fáses por que passa a hemátia até o seu estádio final refere-se sómente ao citoplasma e como tambem, a parte morfológica desses mesmos elementos. pouco nos inieressa no momento, consideraremos então, sómente essas modificações citoplasmáticas que, em resumo, como já foi dito, dizem respeito à hemoglobinisação do glóbulo vermelho.

Voltando agora ao ponto em que tinhamos parado: do hemocitoblasto (FERRATA) ou mieloblasto (NAEGELI) (7) ou "primitive stem cell" (SABin, DoAn e Cunninghan) (8), passamos para o proeritrohlasto que, como o nome indica, é uma célula geradora de eritrocítos. Fáto interessante que se observa nessa fáse é a chamada basofilía paradoxal de FERrata (6) pois, como dissemos, uma célula da série vermelha é tanto mais acidófila quanto mais madura: entretanto aqui o que se passa é justamente. o contrario porque o proeritroblasto que é mais maduro, é mais basófilo que a célula mais jovem de onde deriva - hemocitoblasto. Do proeritroblasto passamos para o eritroblasto basófilo cujo nome é devido, como se depreende, da basofilía do citoplasma; posteriormente a esse estádio, a célula vermelha vae adquirindo afinidade pelos corantes ácidos devido a hemoglobina, de modo que nessa outra fáse, existe uma dupla afinidade: para as côres ácidas e básicas recebendo então a nova célula o nome de eri- 
troblasto policromático ou policromatófilo. Posteriormente, ainda, pela contínua hemoglobinisação, desaparece a afinidade pelas côres básicas e a célula torna-se, então, um eritroblasto ortocromático que, perdendo o núcleo, transforma-se em reticulocíto devido ao aparecimento de uma substancia no seu interior, coravel pelos corantes vi tais e finalmente, temos a hemátia ou eritrocíto madúro, célula acidófila, contendo sómente hemoglobina, e destituida de núcleo.

Em resumo, as diferentes fáses pelas quais passam os eritrocítos até o seu estádio final são: hemocitoblasto - proeritroblasto - eritroblasto basófilo - eritroblasto policromático — eritroblasto ortocromático - reticulocíto - hemátia.

O quadro da pag. seguinte retirado do livro de Varela (Hematologia clínica) é muito elucidativo.

Os autores americanos e inglezes adotam a seguinte terminologia para esses diferentes estádios:

Hemocitoblasto ...................

Proeritroblasto $\ldots \ldots \ldots \ldots \ldots \ldots \ldots$

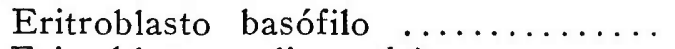

Eritroblasto policromático ..........

Eritroblasto ortocromático ..........

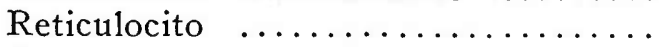

Hemátia ou eritrocito $\ldots \ldots \ldots \ldots \ldots$

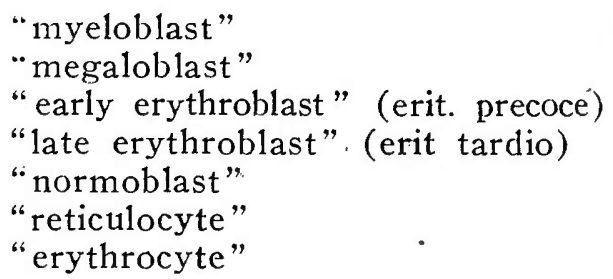

"myeloblast"

"early erythroblast" (erit. precoce)

"late erythroblast". (erit tardio)

"reticulocyte"

"erythrocyte"

Nas 3 primeiras fáses, isto é, proeritroblasto, eritroblasto basófilo e eritroblasto policromatófilo de $1 .^{\mathrm{a}}$ geração, existe divisão cariocinética ao passo que do eritroblasto policromatófilo, na sua segunda geração, até a hemátia não se observa mais a cariocinése.

Nessas diferentes fáses é que agem os diversos fatôres já mencionados: uns, que excitam a eritropoiese (fatôres de excitação ou cito evolutivos) e outros que agem sobre a maturação desses elementos.

Convem assinalar que os americanos chamam de normoblasto o eritoblasto ortocromático.

Antes de tratarmos dos diferentes fatôres que influem sobre a eritropoiése- vamos esquematizá-los da seguinte maneira:

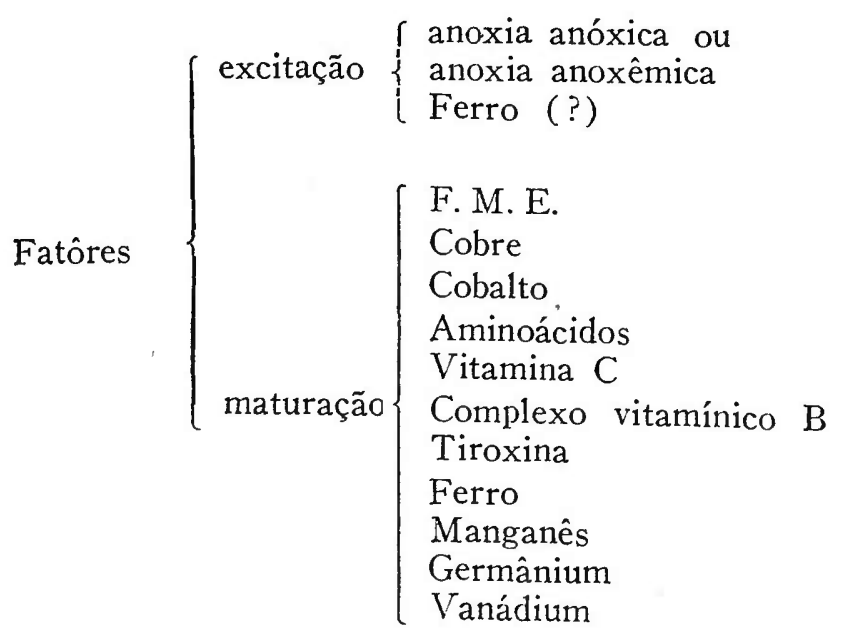




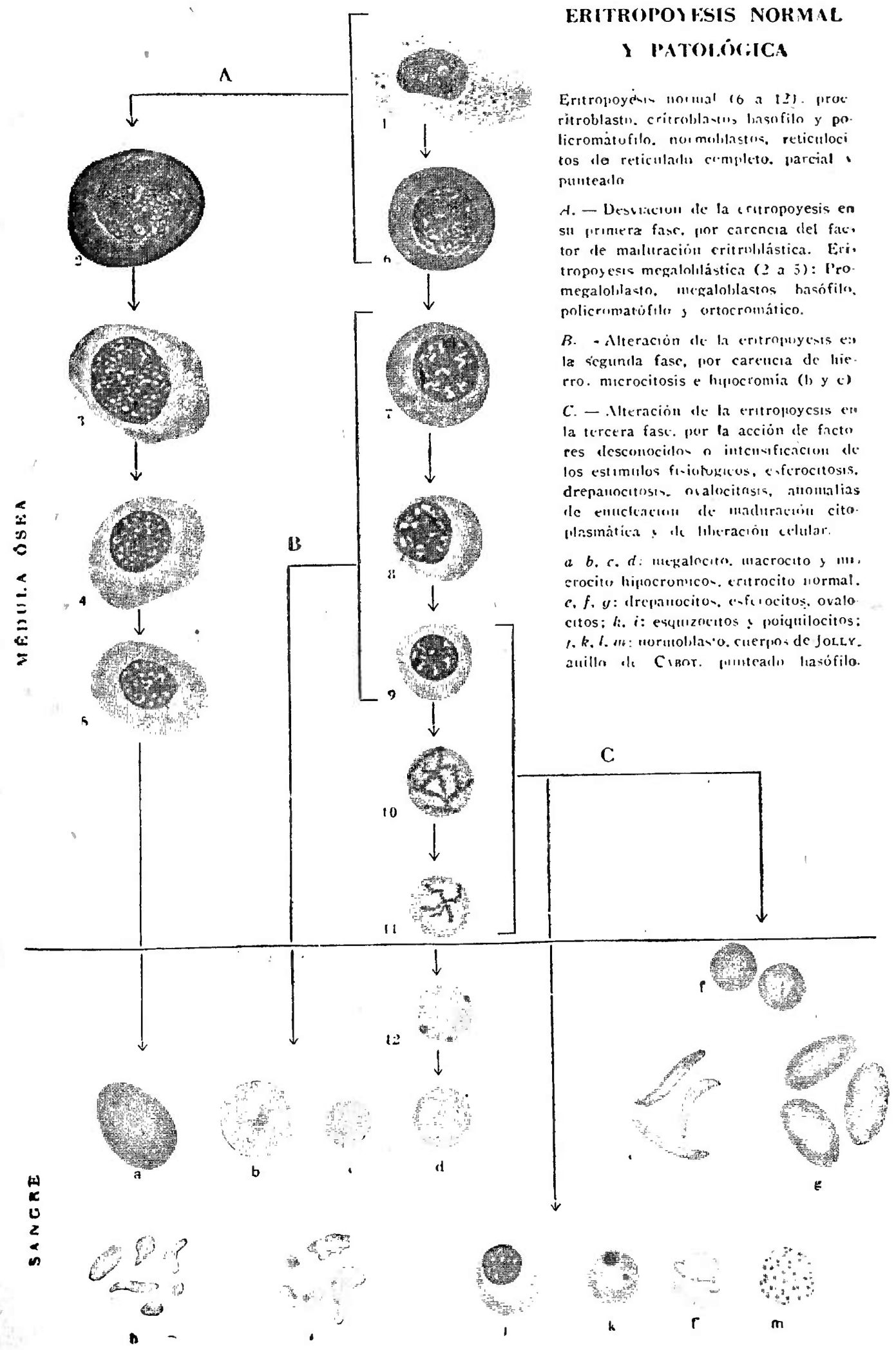


Dos diferentes fatôres que influem sobre a evolução normal dos eritroblastos até o seu estádio adulto - hemátia — citaremos, em primeiro lugar, os de excitação, deixando os de maturação para quando tratarmos da segunda fáse da eritropoiese.

Dos fatôres citoevolutivos, o mais importante e o melhor conhecido é a anoxia ou anóxica ou anoxia anoxêmica dos orgãos hematopoiéticos. De um modo geral, podemos dizer que todas as vêses em que houver diminuição da tensão de oxigênio no sangue, como por exemplo, nas elevadas altitudes, em certos estádios mórbidos como a moléstia de Ayerza, existe uma hiperplasia medular em relação à série vermelha e consequentemente aumento do numero de hemátias no sangue periférico: são as chamadas poliglobulías. Este fáto explíca um achado na médula óssea, interessante e até certo ponto paradoxal, em muitos estados anêmicos. $E$ ' comum encontrar-se, em casos de anemías hipocrômicas com grande baixa da taxa de hemoglobina e dos glóbulos vermelhos, a medúla óssea fortemente hiperplástica relativamente à série vermelha. Explica-se esse fáto pela anoxia pois havendo taxa muito baixa de hemoglobina, a quantidade de oxigênio é diminuida no sangue periférico e essa diminuição é um ótimo excitante da medúla óssea que responde com uma hiperplasía da série vermelha.

Segundo alguns autôres, o ferro é tambem excitante de eritropoiese além do seu papel de maturação dos elementos da série vermelha (formação de hemoglobina). Casos de anemía hipocrômica com pequeno numero de glóbulos vermelhos, quando tratados pelo ferro, melhoram consideravelmente voltando a hemoglobina e o numero dos glóbulos vermelhos ao seu normal, o que parece confirmar o papel excitante do ferro.

As 3 fases (9) em que se divide a eritropoiese são denominadas diferentemente: assim, a primeira é a chamada fáse de eritrogênese e maturação do proeritroblasto; a segunda é a fáse de maturação do eritroblasto e finalmente a terceira é a fáse da eritrogênese definitiva com a consequente emigração das hemátias para o sanguie periférico.

Vejamos, separadamente, cada uma dessas fáses:

1) Fáse de eritrogênèse e maturação do proeritroblasto: Esta fáse comprende a evolução da célula mesenquimal até o eritroblasto basófilo. O mais conhecido dos fatôres que influem nesta fáse é o principio anti-anêmico pernicioso, fração G. de Cohn ou ainda, tambem chamado fatôr de maturação eritoblástica (F. M. E.) (9). A falta desse fatôr provóca uma profunda modificação da eritropoiese dando, como consequencia; a produção de elementos maiores que os proeritroblastos, de núcleo mais esponjoso e no sangue periférico irão aparecer elementos maiores que os normais. E o que sucede na anemía perniciosa. E a esse fenómeno, isto é, proliferação desses novos elementos que normalmente sómente se encontram raros na medúla óssea de criança que se chama gênese megaloblástica. Se- 
gundo Ferrata, essa proliferação megaloblástica é normal no embrião antes do aparecimento do fígado, isto é, na fáse pre-hepática.

O F.M.E. ou princípio anti anêmico pernicioso é formado, segundo a concepção de CASTLE (1-10) pela união de dois fatôres que são, o fatôr extrínseco de Castle encontrado em muitos alimentos e o fatôr intrínseco produzido na mucosa do duodêno e do estômago. A união desses dois fatôres, como dissémos, irá produsir o princípio anti anêmico pernicioso que é armasenado no fígado e que, à medida das necessidades, é fornecido à medúla óssea, para a produção da eritropoiese normal.

A falta dessa fração $G$. de Cohn é que produz a anemia perniciosa. Ha casos em que poderemos ter, não a falta, mas a deficiência do F. M. E: como sucede todas as vêses em que houver diminuição de produção do mesmo ou deficiência de absorção de um dos seus componentes. Assim por exemplo, poderemos ter deficiência desse princípio nos processos de gastrites, gastroenterites, hipoalimentação, processos hépáticos (hepatites, cancer, cirrose hepática, etc.) em que ha diminuição, por parte do fígado, da capacidade de absorção e armasenamento desse mesmo princípio.

E preciso não confundir o megaloblasto da escola de Ferrata com o das escolas americanas. Segundo Ferrata e sua escola, o megaloblasto é encontrado normalmente na fáse pre-hepática do embrião e normalmente, mas raramente, na medúla óssea da criança como foi visto por nós em recente trabalho (11). Patológicamente essa célula é encontrada na anemia perniciosa e em algumas fórmas de eritremía. Os americanos chamam de megaloblasto ao proeritroblasto e daí a confusão reinante ₹para quem, pela primeira vês, põe-se em contato com tal assunto.

Outra confusão que tambem não deve ser feita é entre o princípio anti anêmico pernicioso e o princípio anti anêmico secundário ou fração de Whipple (12) ; são dois princípios completamente diferentes, quer do ponto de vista físico-químico, quer do ponto de vista biológico e terapêutico.

O primeiro — princípio anti anêmico pernicioso - age somente sobre as anemías macrocíticas de um modo geral, é soluvel no alcool a $70 \%$, relativamente resistente ao calôr (90 a $95^{\circ}$ durante 30 a $60^{\prime}$ ), soluvel na agua, fenol, glicerol, clorofórmio, precipita-se no alcool fosfotúngstico e com sal de Reinecke. O segundo, - fração de Whipple - que tambem existe no fígado, age única e exclusivamente sobre as anemías hipocrômicas, é insoluvel no alcool a $70 \%$, solúvel ņa agua e no alcool em baixa concentração, insolúvel no eter, e em grande parte dos solventes orgânicos.

A segunda fáse é a chamada fáse de maturação do eritroblasto: que compreende, do eritroblasto basófilo ao policromatófilo inclusive. Nesta fáse ainda ha mitoses e, ao mesmo tempo que se processam essas mitoses, aparecem processos que teem por fim trazer o amadurecimento, principalmente do citoplasma do eritroblasto. 
A existência das mitoses nestas duas primeiras fáses é de grande importancia pois é pelo seu estudo que fazemos a curva cariológica de Introzzi e Fieschi (13) para se avaliar da capacidade de excitação eritropoiética ou capacidade eritrocito evolutiva da medúla óssea.

Alen das modificações nucleares que se processam nesta fáse e que para nós têm relativamente pouca importancia, verificam-se modificações para o lado do citoplasma sendo a formação da hemoglobina a que mais nos chama a atenção. Os elementos, à medida que vão evoluindo para o estádio adulto vão adquirindo maior quantidade de hemoglobina até a sua completa saturação. Dos fatôres mais importantes para a maturação desses elementos, nesta fáse, poderemos citar: cobre, cobalto, aminoácidos, vitamina $\mathrm{C}$, complexo vitamínico B, tiroxína e ferro.

Cobre: Quanto ao papel verdadeiro que ele exerce sobre as anemías, nada está perfeitamente assentado mas parece, pelas experiências que se tem feito que ele age exclusivamente como catalisador sobre a síntese da hemoglobina ou libertando o ferro do fígado ou então, convertendo o ferro armasenado en uma fórma química adequada para a sua introdução na molécula de hemoglobina. Ele não possue nenhuma ação sobre a absorção do ferro.

Interessante é o fáto de que os moluscos e artrópodas possuem um pigmento respiratório que contem cobre - hemocianina $(30)-$ cuja função é identica à da hemoglobina. Este pigmento contem cobre mais ou menos na mesma porcentagem em que o ferro entra na constituição da hemoglobina $(0,34 \%)$.

Frost e Elvehjen (14) demonstraram que, quando se alimenta um animal tornado anêmico por sangrías repetidas, sómente com leite, não ha elevação da taxa de hemoglobina nem dos glóbulos vermelhos o que sómente se verifica quando a essa diéta se juntarem traços de cobre.

Elvehjen e Sherman (15) fizeram mais ou menos a mesma experiência que os autôres anteriores verificando que o ferro puro, administrado a ratos anêmicos con diéta láctea exclusiva, depositava-se no fígado e baço e não havia aumento de hemoglobina; a administração de cobre a esses animais juntamente com a diéta aumentou a hemoglobina e diminuiu os depósitos de ferro acima assinalados.

Raramente verifica-se deficiência desse metal na alimentação porque quasi todos os alimentos o conteem em quantidade suficiente para as necessidades orgânicas.

Dos alimentos ricos em cobre, poderemos citar: fígado, chocolate, castanha do Pará, melado, cogumélo, nozes, farelo de trigo, germe trigo. Alimentos que conteem em menor proporção: maçã, repôlho, cenoura, uva, "Grape fruit", limão, alface, cebola, laranja, tangerina, tomate, melão d'agua, etc.

Cobalto: Na Nova Zelandia, Austrália, Flórida, alguns países do Atlantico Sul, etc., conhece-se, ha muito tempo, uma moléstia que atinge sómente carneiros e gatos, conhecida por varios nomes (coast 
disease, bush sickness, wasting disease etc.) e cujo quadro hematológico.é o de uma anemía microcítica hipocrômica. Como muitos desses animais não melhoravam com a ferroterapia procurou-se a causa dessa anemía examinando-se o sólo. O exame revelou, nessa zona uma deficiência de cobalto no solo que foi considerada como a responsavel por essa moléstia, pois que a adminitraçãos desse mineral aos animais doentes e que não respondiam à ferroterapia, curava completamente a enfermidade.

WAltner e Waltner (16) administrando cobalto a ratos conseguiram produsir policitemía sendo esse mesmo fáto confirmado por ORTEN (19) que tambem mostrou haver aumento do volume de células sem modificações do volume do plasma. Este último autôr verificou, administrando cobalto a ratos adultos ou jovens, uma reticulocitóse no quarto dia e um estado policitêmico no fim de 6 semanas. Orten acredita que a policitémia pelo cobalto é devida a um aumento da hemoglobina e glóbulos vermelhos e não a uma diminuida destruição desses últimos.

Segundo BARron e BARron (17) o cobalto inibiria a função respiratória dos glóbulos vermelhos imatúros na medúla óssea, que passariam então, em maior quantidade, para a corrente circulatória resultando daí a policitemía.

Frost (18) e colaboradores concluem em trabalho por eles realisado que a falta de dados certos quanto à ação do cobalto é devida, ou à falta de especificidade de sua ação ou ao inevitavel cobalto de sua diéta experimental que provavelmente supriría as necessidades orgânicas, falseando dessa maneira os resultados.

Pelo exposto verifica-se que, embora pareça ter o cobalto alguma ação sobre à hematogênese, nada está completamente esclarecido.

Amino ácidos: Dos amino ácidos tidos como responsáveis por muitos estados anêmicos em que ha deficiente formação de globina, constituinte da hemoglobina poderemos citar especialmente a glycina, ácido glutámico, histidina, ácido aspártico, cistina, fenilalanina e prolina (20), amino ácídos esses que, como foi demonstrado em animais de experiencia, elevam o nivel da hemoglobina, fáto este que não se observa si tratarmos esses mesmos animais sómente com o ferro.

Vitamina $C$ : E de conhecimento geral que a deficiência ou a falta de vitamina C. produz o escorbuto acompanhado de uma anemía quasi sempre mormocítica e algumas vêses macrocítica. Os autôres referem que a administração de vegetais e frutas cura essa anemía juntamente com o escorbúto dando este fáto como prova terapêutica da causa da anemía (vit C.).

Mettier, Minot Townsend (21) afirmam que, pelo menos em certos casos, a falta de vitamina $\mathrm{C}$ é a causa da anemía. Alimentaram seus pacientes com ferro e estráto de fígado mas sem vitamina $C$, não 
notando a melhora da anemía; o acrescimo de vitamina $\mathrm{C}$ (sob a forma de suco de laranja ou polpa de fígado crú, alimentos esses ricos em vitamina C) tinha efeito notavel sobre a cura dessa anemía. Deve-se notar, entretanto, que o suco de laranja e outros alimentos usados por esses autôres conteem, alem da vitamina $\mathrm{C}$, outros elementos como ferro, vitamina A e complexo B.

BARron e BARron (17-22) mostraram um papel importante da vitamina $C$ na manutenção do nível eritrocítico fisiológico do sangue periférico: a policitemía que aparece quando se injéta sulfato de cobalto em coelhos deixa de existir si juntarmos ao sulfato de cobalto, a vitamina $\mathrm{C}$.

LOZNER (23) não encontrou ação nenhuma da vitamina C. sobre as anemías em 5 casos por ele experimentados. Tratava-se de 5 doentes com deficiência de vitamina $\mathrm{C}$ evidenciada pela dosagem do ácido ascórbico no plasma: 3 desses pacientès apresentavam sinais clínicos de escorbúto, um apresentava pelágra e outro anemía hipocrômica idiopática. Esse A. administrou ferro e diéta com baixo teôr de vitamina $\mathrm{C}$ e complexo B. Pois bem, a melhora em 4 pacientes se deu espontâneamente ou em resposta ao ferro pelo que o autôr conclue que a regeneração hemoglobínica póde ocorrer na presença de ácido ascórbico reduzido no plasma.

Outro fáto digno de nota é o seguinte: a deficiência dietética de vitamina $\mathrm{C}$ sómente, em um indivíduo são, produz o escorbúto sem qualquer sinal de anemía, mesmo que se produzam sangrías repetidas chegando a um total de 6.000 cc como já foi demonstrado. $O$ que parece certo é que a anemía quando presente no escorbúto é devida não sómente ao estado de hiponutrição que geralmente se encontra nesses indivíduos como tambem às hemorragias repetidas que nessa moléstia se verificam, acompanhadas de uma queda do estado geral.

Recentemente Lozner (23) verificou que, em individuos com deficiência de vitamina $\mathrm{C}$, a hemoglobina eleva-se ao nível normal espontâneamente ou com a ferroterapia sem a adição da vitamina $C$ à diéta.

Pelo esposto, verificamos que fátos ha que mostram a eficiência da vitamina $C$ sobre a hematopoiese e outros fátos provam o contrário. Entretanto poderemos dizer que si a vitamina $\mathrm{C}$ tem alguma ação sobre a hematopoiese o seu mecanismo íntimo não é conhecido.

Complexo vitamínico $B$ : Ao contrário do que sucede com a vitamina $C$, certos dos constituintes do complexo $B$ teem influência sobre a formação dos elementos vermelhos do sangue, principalmente piridodina - vitamina $\mathrm{B}_{6}$ - que cura a anemía de animais alimentados com a diéta sem esse fatôr. Street, Cowgill e ZimmerMANN (24) obtiveram anemías graves em cães com diétas deficiêntes em vitamina $B_{6}$ : verificaram o aparecimento dessa anemía 120 a 320 dias após o início da diéta que era prontamente melhorada com a administração dessa vitamina. 
Além desse constituinte, a riboflavina, ácido nicotínico e, provavelmente, algum outro constituinte desse complexo podem ter ou teem mesmo ação sobre a hematopoiese.

Tiroxina: E comúm observar-se a melhora de uma anemía de um mixedematoso pelo tratamento dessa moléstia com a tiroxina. Muitos autôres afirmam que a tiroxina aumenta o metabolismo geral e, consequentemente, o dos orgãos hematopoiéticos advindo daí a melhora da anemía. Segundo afirma Wintrobe (25) quando se encontra anemía no mixedema esta é de leve gráo e a administração de tiróide não produz resposta reticulocitária. A anemía dos estados hipotiróideos é explicada, a maior parte das vêses, por uma hipocloridría que geralmente acompanha esses estados hipofuncionais daquela glândula e que impede a absorção do fatôr extrínseco da alimentação (anemía macrocítica) ou do ferro (produção de anemía microcítica ou normocítica hipocrômica) ou de ambos (anemía macrocítica hipocrômica).

Quando a um hipotiróideo com anemía hipocrômica, administramos ferro juntamente com tiroxina, a volta da hemoglobina e glóbulos vermelhos ao nível normal é muito mais rápida do que si administrássemos sómente tiróide. Em 53\% dos casos de mixedema pode-se verificar acloridría alem disso, é comum a anorexia, o que trás como consequência uma carência alimentar e portanto deficiência principalmente de fatôr extrínseco e ferro, resultando dahi, as anemías hipocrômicas ou as macrocíticas conforme a deficiência, como já foi citado.

Fração anti anêmica secundária ou fração de Whipple (26): WHIPPLE produziu anemía hipocrômica em cães fazendo-lhes sangrias repetidas. Alimentou-os depois, com uma fração de fígado insoluvel no alcool a $70 \%$ obtendo uma resposta hemoglobínica o que levou à conclusão de que esse efeito não era devido ao conteúdo em ferro desse princípio que aí se acha em estado ferroso mas sim ao proprio princípio insolúvel no alcool a $70 \%$. Experiências feitas por outros autôres chegaram a corfclusões contrárias atribuindo „esse efeito ao ferro contido nessa fração pois o tratamento sómente com esse metal produzia uma melhora muito mais rápida.

Ferro: De todos estes fatôres o ferro é o mais importante visto ser um dos componentes primordiais da molécula de hemoglobina: A deficiência de ferro impede a formação de adequada quantidade de hemoglobina e como consequência as hemátias serão hipocoradas originando-se assim as anemías hipocrômicas. A quantidade total de ferro existente no organismo orça, mais ou menos, em 4 gramas sendo que mais de $3 / 4$ partes encontram-se na molécula de hemoglobina donde se dedús a sua importância para a mesma. Visto serem as anemías hipocrômicas consequências da deficiência de ferro em sua grande maioría, poderemos deduzir de antemão, que todas as causas capazes de trazer perturbações para o lado do aproveitamento do ferro ingerido ou para o lado da formação de hemoglobina, origi- 
narão essas anemías. Assim os processos do aparelho digestivo, as hemorragías, a hiponutrição, as verminoses, etc. etc.

A título de curiosidade apenas, citaremos alem dos fatôres já assinalados para a hematopoiése o manganês, germanium, vanadium que parecem ter alguma influência sobre a formação de hemoglobina e cujo mecanísmo é desconhecido.

Vista em linhás gerais a segunda fáse da eritropoiése e feitas algumas considerações sobre os fatôres de maturação passaremos agora para a terceira fáse, ou

Fáse de eritrogênese definitiva e emigração do eritrocíto: Como vimos, esta fáse compreende o eritroblasto ortocromático, os reticulocítos e as hemátias. O eritroblasto ortocromático, quando não ha deficiência de nenhum fatôr de maturação, acha-se saturado de hemoglobina e com o seu núcleo picnótico pronto para ser eliminado. Eliminado o núcleo por cariorexis, cariolise ou expulsão total pașsaremos para o reticulocíto que se encontra na porcentagem de 0,5 a $1,0 \%$ normalmente no sangue periférico para substituir as hemátias que constantemente são destruidas nos orgãos hematopoiéticos principalmente baço e fígado.

Sería interessante si fizéssemos algumas ligeiras considerações sobre esse elemento, visto que o exame para a sua pesquisa é accessivel a qualquer médico não especialisado e o seu estúdo nos fornece dados importantissimos principalmente quando se trata da terapêutica das anemías.

Os reticulocítos são hemátias jovens e cuja presença no sangue circulante nos dá a idéia da atividade eritropoiética da medúla óssea. Quanto maior é a quantidade de reticulocítos no sangue periférico maior é a atividade dos orgãos hematopoiéticos. A sua pesquisa no sangue periférico é facílima sendo conveniente repetirmos a técnica usada por nós, para a sua evidenciação. Repetiremos a técnica já descrita em trabalho anterior que fizemos em colobaração com o Dr. E. M. Russo (27). Após a punção da polpa digital e despresada a primeira gôta de sangue, coloca-se numa lâmina uma segunda gôta e logo após mistura-se essa gôta com uma outra igual retirada por meio de um pequeno bastão de vidro, do corante vital, azul de cresil brilhante; fazem-se pequenos movimentos circulares com o proprio bastão de vidro procurando misturar o mais possivel o corante com a gôta de sangue, mistúra esta que será, perfeita, quando adquirir uma côr vinhosa escúra. Neste momento, então faz-se um esfregaço com o bordo de outra lâmina cuja técnica é por todos nós conhecida levando-se em conta apenas o ângulo formado pelas duas lâminas ao fazer o esfregaço que deve ser de, no maximo, 30 gráos afim de se obter um esfregaço cujas hemátias sejam bem separadas facilitando desse modo a contagem das mesmas. Feito o esfregaço, córa-se pelos métodos comuns. (Leischmann, May Grünwald-Giemsa, etc.).

Como dissemos, os reticulocítos indicam um índice de atividade eritropoiética. Sería de conveniência lembrar que podemos ter re- 
ticulocitoses fisiológica e irritativa. A primeira, é uma resposta normal da medúla óssea seguida de aumento dos glóbulos vermelhos ao passo que a segunda é apenas uma irritação medular não seguida de aumento das hemátias. Este fáto é importante ser conhecido para evitarmos interpretações errôneas considerando um medicamento como excitador da eritropoiése ou como antianêmico quando na realidade funciona apenas como elemento irritativo (arsenito de potassio sob a forma de Licor de Fowler segundo Castle e Minot).

A atividade de um preparado sobre a cura das anemías é verificada principalmente pela resposta reticulocitária e aumento dos glóbulos vermelhos e hemoglobina conforme o medicamento considerado. O controle do efêito dos estrátos hepáticos é verificado pela resposta reticulocitária existindo para isso fórmulas especiais que nos dão o valôr ótimo da resposta à injeção intra muscular do estráto hepático. A mais conhecida é a fórmula citada por IsaAcs e Friedman (28) :

$$
\mathrm{R}=\frac{1+0,5 \mathrm{Eo}_{\mathrm{o}}}{82-22 \mathrm{Eo}}
$$

em que $\mathrm{R}$ é a resposta reticulocitária e Eo corresponde ao número inicial em milhões de glóbulos vermelhos por milímetro cúbico. Assim, si tivermos por exemplo um caso com 2.500 .000 glóbulos vermelhos por milímetro cúbico inicialmente, o estráto hepático será considerado ótimo si uma unidade desse estráto administrada intramuscularmente produzir a seguinte resposta reticulocitária:

$$
\mathrm{R}=\frac{1+0,5 \mathrm{Eo}_{\mathrm{o}}}{82-22 \mathrm{E}_{\mathrm{o}}}=\frac{1+0,5 \cdot 2,5}{82-22 \cdot 2,5}=\frac{2,25}{27}=12,0 \%
$$

Outra noção importante é a seguinte: si por hipótese, o estráto administrado no caso anterior der os $12 \%$ assinalados e si injetarmos depois um outro estráto hepático que der uma resposta maior do que a dada pelo primeiro, este segundo estráto é considerado melhor que o anterior. É a essa prova que se dá o nome de prova da "segunda resposta reticulocitária" (29) sendo muito usada para se comparar e avaliar a potência dos diversos preparados.

Até agora, falámos apenas dos estrátos hepáticos. É preciso. lembrar-se que quando se administra ferro, tambem se obtem uma resposta reticulocitária; não querendo isto dizer que o ferro é que produz os glóbulos, ele apenas entra na constituição da hemoglobina. A resposta reticulocitária neste caso é explicada não só pela provavel ação excitante do ferro como tambem pela introdução no organismo, devido à melhora do estado geral,, de fatôres de maturação para a hematopoiése, substâncias estas deficientes anteriormente, devido a causas várias consequentes aos estados anêmicos (gastrites, hipo ou acloridría, perturbações gastro intestinais, anorexia, hipoalimentação, 
etc.). De modo que a administração esclusiva de ferro é o suficiente para melhorar as condiçôes gerais do indivíduo e desse modo supril-o de outros materiais acessórios que são introdusidos no seu organismó com a propria alimentação.

Teremos a oportunidade de voltar sobre esse ponto quando discutirmos o assunto dos medicamentos muito bem rotulados pelos autôres americanos de "shot-guns".

A intensidade da resposta reticulocitária está na razão inversa do número inicial dos glóbulos vermelhos: - assim, quanto menor o número de glóbulos inicial, máior será a resposta reticulocitária.

Fáto interessante é o seguinte: muitas vêses pode-se suspeitar da existência de hemorragías ocultas pela contagem dos reticulocítos no sangue periférico. Assim, esse método pode ser uma bôa pista diagnóstica para muitos processos do tubo digestivo como úlceras gastro duodenais, verminóses, retites ulcerativas, etc. etc..

Alem desses dados importantes que nos podem oferecer os reticulocítos podemos ainda, por meio deles, nos certificar da eficiência ou não de um tratamento antianêmico administrado.

Visto assim alguma cousa que se refere aos reticulocítos passaremos à fáse seguinte: a das hemátias.

A eritropoiese segundo está afirmado, é intravascular e o que se observa em cortes histológicos é que as células, à medida que vão evoluindo para as fórmas mais adultas vão se colocando na perifería dos capilares sinusoidais dos orgãos hematopoiéticos e depois, por um mecanismo de que pouco se sabe a respeito, são lançados para o sangue periférico onde vão desempenhar a sua missão. Porque normalmente não são lançados no sangue circulante as hemátias nucleadas não se sabe com certesa. O que se verifica é o seguinte: todas as vêses que a medúla óssea fôr solicitada de uma maneira muito intensa de modo que não consegue suprir as necessidades, ela lança na corrente circulatória hemátias jovens, mas fáto interessante, nunca lança de uma maneira desordenada fisiológicamente falando, quer dizer, nunca encontramos, por exemplo, eritroblastos basófilos sem se encontrar as fáses mais adultas em primeiro lugar. Isto significa que o lançamento na corrente sanguínea segue uma hierarquía relativamente aos estádios evolutivos. E a esse fenomeno que os autôres americanos chamam de "resposta escalonada".

Dissémos anteriormente, "fisiológicamente falando" porque em estádios em que a resposta não é normal (eritremías, eritroleucemías, anemía aplástica) não existe esta reação ordenada.

Lançados os eritrocítos na corrente circulatória vão eles desempenhar a sua função principal que é o transporte de oxigênio aos te-
cidos.

E pelo exame do tamanho, conformação, coloração desses elementos do sangue periférico que tiramos conclusões sobre os estados anêmicos e suas provaveis causas. 
$\mathrm{O}$ que descrevemos até agora foi a eritropoiese normal. A falta ou deficiência daqueles fatôres já refericlos é que irão produzir modificações na eritropoiese cuja repercussão no sangue periférico é a anisocitóse (diferença no tamanho das hemátias), poiquilocitose (dif́rença de fórma), policromatofilía (mudança de coloração), macrocitose (aumento do diâmetro médio das hemátias, devido a uma deficiência ou falta do F. M. E.), microcitóse (diminuição do diâmetro médio), corpos de Howell-Jolly (eliminação incompleta do núcleo), anel de Cabot (restos nucleares), ponteado basófilo (restos cromatínicos), hipocrômia das hemátias (deficiência de hemoglobina e consequentemente do ferro) ou então associação desses diversos achados conforme a causa da anemía. Podemos ter tambem presença de eritroblastos, etc. (v. fig. pg. 23). Feitas essas considerações a respeito do eritrônio, eritropoiese e fatôres que a influenciam passaremos, em seguida, ao estudo das anemías tendo sempre em mente que o nosso estudo será quasi que exclusivamente relativo à parte prática deixando portanto de lado as considerações teóricas a respeito, principalmente, das divisões feitas pelos diversos autôres das anemías o que viría trazer uma enorme confusão dificultando assim a nossa tarefa.

Com um estudo e um apanhado geral sobre a divisão das anemías de um ponto de vista prático veremos que a adotada por nós não só é muito fácil como tambem para os médicos não especialisados serve de um ótimo guia principalmente para o tratamento das mesmas. É claro que a divisão que iremos fazer é muito falha, pois fica de lado grande parte das anemías cuja patogenía está bem esclarecida, mas como nesse trabalho procuramos não sómente tratar das anemías mais comuns como tambem queremos discutir quasi que exclusivamente as anemías hipacrồmicas, é que deixaremos de parte as outras.

Definimos a anemía como um deficit funcional do eritrônio, isto é, anemía são todos aqueles estados sanguíneos em que ha diminuição ou da taxa de hemoglobina ou dos glóbulos vermelhos ou de ambos. Assim poderemos ter estados anêmicos em que ha ou sómente a diminuição da taxa de hemoglobina ou sómente do número dos glóbulos vermelhos. '

Diferença importante que devemos fazer para que não possamos considerar um estado como anêmico quando na realidade não o é, é com as volemias, isto é, aumento da quantidade de plasma circulante como acontece na gravidês, molestias cardíacas, nefropatías, єtc. Nesses estados existe aumento da quantidade total de líquido circulante e no entanto não ha diminuição do número de glóbulos vermelhos nem da hemoglobina totais. Entretanto, si fizermos a contagem encontraremos diminuição de ambos. O contrário tambem pode ser verificado, isto é, quando ha grande desidratação do indivíduo como sóe acontecer nas diarréas, vômitos, suôres intensos, febre, etc., a quantidade percentual de hemoglobina e o número de hemátias por milímetro cúbico é maior do que o normal ao passo que se considerarmos o volume total do sangue circulante veremos que se man- 
tem normal. Estes estados comumente são confundidos com outros em que existe na realidade aumento desses elementos constituindo as poliglobulías, por exemplo. Seria interessante mencionarmos agora alguns termos não muito usados por motivos que logo veremos mas cujo conhecimento não é de todo inutil:

1) oligoemía: redução da quantidade total de sangue, lhos,

2) oligocitemía: redução do número total de glóbulos verme-

3) oligocromemía: redução da quantidade total de hemoglobina do organismo.

Esta terminologia é muito pouco usada como dissemos porque raramente, para os estudos clínicos, mede-se a quantidade total do sangue circulante mas sim a quantidade de hemoglobina e número de glóbulos vermelhos em uma unidade de volume (100 cc. de sangue e milímetro cúbico respetivamente).

Vários são os pontos de vista sob os quais os diferentes autôres classificam as anemías. Entretanto, adotaremos apenas a classificação mais simples, a morfológica que embora falha e não conter um certo número de anemías, nos dá ótimas informações quanto ao tratamento e é acessivel a qualquer médico não especialisado.

Esta classificação baseia-se em 3 dados:

1) tamianho das hemátias (dado pelo seu diâmetro médio)

2) porcentagem de hemoglobina

3) valôr globular tambem chamado índice colorimétrico ou V. G. obtido partindo-se dos dois primeiros dados.

Normalmente as hemátias teem de diâmetro médio 7,2 a 7,8 micra. As hemátias com valôres acima são consideradas macrocíticas e abaixo, microcíticas. Esses números podem ter variações com a idade, sexo, variações diurnas cujo conhecimento é de pouco valôr para nós, no momento. A hemoglobina normalmente existe em média 14,5 grs por $100 \mathrm{cc}$. de sangue. A esse valôr médio normal as autôres convencionaram chamar $100 \%$ e que corresponde a $105 \%$ na escala de Haldane e $85 \%$ na escala de Sahli o que nos mostra que $100 \%$ é um número abstrato cuja consequência veremos daqui ha pouco. Normalmente existe como termo médio, 5.000.000 de hemátias por milímetro cúbico havendo variações individuais e quanto ao sexo.

Pois bem, o V. G. nada mais é que a relação entre a porcentagem de hemoglobina e o número de hemátias em centenas de milhares multiplicado por 2. Portanto, si 5.000 .000 é considerado $100 \%$ do normal $(50 \times 2=100)$ e 14,5 grs de hemoglobina é considerado

$100 \%$ do normal o V. G. será : $\frac{100}{50 \times 2}=\frac{100}{100}=1$ isto é, o V. G. 
é igual a 1. Ora, podemos verificar que estamos fazendo a relação entre duas quantidades arbitrárias e variaveis e consequentemente o quociente será tambem variável. Entretanto, embóra seja um valôr variável fornece-nos dados importantes e por esse motivo conservalo-emos.

Quando o V. G. é igual a 1 dizemos que a hemátia é normocrômica, quando menor hipocrômica e quando maior hipercrômica. $\mathrm{O}$ termo hipercrômica só póde ser aceito com reservas pois uma hemátia só póde conter hemoglobina até a sua saturação cujo valor será 1 ., seria pois absurdo dizer que a hemátia contem mais hemoglobina que a sua propria saturação. O que sucede é o seguinte: quando uma hemátia tem um V. G. maior do que 1 é porque ela é macrocítica, quer dizer, maior do que o tamanho normal e consequentemente si a sua saturação de hemologlobina fôr completa forçosamente ela conterá mais hemoglobina do que uma hematia normal. Nunca temos V. G. maior do que 1 quando a hematia fôr normocítica (salvo as anemías esferocíticas em que todos os dimametros da hemátia estão aumentados). Em resumo, quando dizemos que uma hemátia é hipercrômica queremos com isto dizer que contem hemoglobina em maior quantidade do que uma hemátia normal, porem não está supersaturada pois fisiológicamente é impossivel uma saturação aumentada (29).

De acôrdo então com o critério do $\mathrm{V}$. G. poderemos dividir as anemías em hipercrômicas, normocrômicas, ou hiporcrômicas conforme o V. G. fôr, respectivamente, maior, igual ou menor do que 1.

O segundo critério é o do diâmetro médio das hemátias. Podemos, em linhas gerais dizer que o tamanho das hemátias para maior é condicionado pela deficiência ou falta de F. M. E. O tamanho para menor é devido a outras causas que não nos interessam no momento (adaptação, por parte da medúla, do continente ao conteúdo ( $\mathrm{Hb}$ ). A deficiência do F. M. E. verifica-se por diversas causas cujas principais são:

1) ausência de fatôr extrínseco; hipoalimentação, perturbações do aparelho digestívo que impedem a sua absorção.

2) - ausência de fatôr intrínseco; gastrites, cancer do estômago ou qualquer outra causa que impeça a sua fabricação pela mucósa do estômago e duodeno (40).

3) presença de fatôr in e estrínseco e F. M. E. mas deficiência de armasenamento do último por perturbações hepáticas (cirroses, cancer do fígado etc.) (41).

4) presença de F. M. E. no fígado mas deficiência de aproveitamento desse princípio por parte da medúla óssea (anemía acréstica segundo a,denominação de IsRaEls e WILKINSON) (31).

5) gravidês: provavelmente por retirada, por parte do féto, de todo o F. M. E. existente no fígado materno que não recebe a quantidade suficiênte para si e para o futuro filho. 
O tamanho da hematia (continente) e a quantidade de $\mathrm{Hb}$ (conteúdo) são condicionados por dois fatôres independentes do ponto de vista fisiológico: um não a'ge no outro setôr. Este fáto tem importância grande do ponto de vista prático para a compreensão da patogenía e tratamento das anemías.

De acôrdo com o diâmetro das hemátias dividimos as anemías em macrocíticas, normocíticas conforme o diâmetro médio das hemátias fôr, maior, igual ou menor respetivamente, que o diâmetro normal.

Em resumo, de acôrdo com a quantidade de $\mathrm{Hb}$ teremos as anemías hipercrômicas, normocrômicas e hipocrômicas e de acôrdo com o diâmetro médio, macrocíticas, normocíticas e microcíticas.

Poderemos ter associação desses dois fatôres e de acôrdo então com esse fáto é que dividimos as anemías em:

$\begin{array}{cl}\text { Normocíticas } & \left\{\begin{array}{l}\text { normocrômicas } \\ \text { hipocrômicas } \\ \text { hipercrômicas }\end{array}\right. \\ \text { Macrocíticas } & \left\{\begin{array}{l}\text { normocrômicas } \\ \text { hipocrômicas }\end{array}\right. \\ \text { Microcíticas } & \left\{\begin{array}{l}\text { normocrômicas } \\ \text { hipocrômicas }\end{array}\right.\end{array}$

Trataremos sómente das anemías hipocrômicas, ferroprivas, cujo V. G. é portanto, menor do que 1. Citaremos as suas causas principais e em seguida, cogitaremos do seu tratamento. citar :

Das causas mais comuns das anemías hipocrômicas poderemos

Hipoalimentação: pequena ingestão de alimentos, deficiência endocrina, utilisação deficinte dos alimentos.

Intoxicação agúda e crônica : - saturnismo.

Processos infeciosos agúdos, supurativos: pneumonía, septice- . mía, reumatismo poli articular agúdo, abcesso pulmonar, etc. etc.

Processos crônicos: reumatismo crônico, nefrite crônica, endocardite, tuberculose, sífilis, etc.

Hemorragías crônicas: úlceras gastro duodenais, retites ulcerosas, etc.

Hemorragia agúda. trauma, metropatia hemórrágica, etc.

Verminoses: ankilostomose, botriocefalose, etc. etc.

O tratamento desses diferentes tipos de anemía, é sempre o mesmo isto é, administração de ferro.

\section{TRATAMENTO}

É comum na prática administrar-se estráto hepático para o tratamento das anemías hipocrômicas. Teóricamente é um dos meios de tratamento pois o fígado alem do F. M. E. contem, ferro, vitaminas, aminoácidos indispensáveis à eritropoiese. Dizemos teóricamente por- 
que na prática, verifica-se que, pelo menos em $95 \%$ dos casos de anemías hipocrômicas, sómente o tratamento marcial é o suficiente. As únicas exceções em que a ferroterapia é sem valôr na anemía hipocrômica são a anemía de Cooley (anemía do. Mediterrâneo) e a anemía produzida em cães pela avitaminose $\mathrm{B}_{6}(32)$.

Compreende-se que o estráto hepático seja útil ao tratamento das anemías hipocrômicas, mas de outro lado o tratamento bem orientado sómente com o ferro melhora as condições gerais do doente e com esta melhora o organismo recebe pela alimentação todas as outras substâncias indispensáveis à eritropiése que por ventura faltem nesses estados anêmicos devido a hipoalimentação. $O$ fígado contem, tambem, a fração de, Whipple além do ferro e outros fatôres já assinalados. Essa fração age exclusivamente sobre as anemías hipocrômicas. Pois bem, na preparação do extráto hepático ha precipitação desse princípio ficando praticamente nula a ação desse estráto de fígado sobre a anemía hipocrômica. Além disso pouco se sabe a respeito desse princípio antianêmico porquanto ha autôres que afirmam ser a sua ação sobre as anemías hipocrômicas, devida exclusivamente ao seu conteúdo em ferro ao passo que os outros autôres atribuem o seu efeito â própria fração de Whipple.

De um um modo ou de outro os estrátos hepáticos não teem ação sobre as anemías hipocrônticas, ou si tiverem é pequena, o que não justifica o seu emprêgo no tratamento dessas anemías a não ser em casos especiais. Alem disso raramente encontramos deficiência de F. M. E. nas anemías hipocrômicas sendo essa outra razão que não justifíca o uso desse estráto no tratamento dessas anemías.

A administração de vit. C. cujo valôr já discutimos, vit. $B_{6}$ e outros fatôres juntamente com o ferro é outro procedimento que não tem muito fundamento pois como dissémos, a propria melhora do estado geral do doente quando submetido ao tratamento marcial, faz com que ele, por uma melhor alimentação, principalmente sị científicamente orientada, introduza no seu organismo não só os fatôres já assinalados como tambem outros provaveis que não conhecemos presentemente.

Tem muita razão Wintrobe quando discute a questão de muitos medicamentos que contêm um grande numero de fatôres para a hematopoiese e cujo preço é exorbitante ficando o preço do tratamento fóra do alcance de muitas bolsas. Wintrobe chama a esses produtos "shot-guns" (25) quer dizer, remédios cuja ação é comparada a um tiro de espingarda que tendo muito chumbo um destes atingirá de uma maneira ou de outra o alvo.

Além disso, essa prática não é útil porque si houver necessidade maior de um dos elementos constituintes do preparado esse elemento aí se acha em tão pequena quantidade que não supre as necessidades do caso, pois as dóses poderão não estar no seu ótimo terapêutico. O resultado, diz Wintrobe, é grande dispêndio monetário e de tempo 
do paciente e discrédito do médico. A administração, por exemplo, de ferro necessario dado sob essa fórma de "shotgun terapia" custará ao paciente cerca de 30 vêses mais do que si the fôr dado sómente o ferro de que ele necessita.

Interessante é o gráfico mostrado por WINTROBE e que reproduzimos aqui. Como se vê, o custo de uma "shot-gun" terapia chega a $\$ 1.20$ por dia.

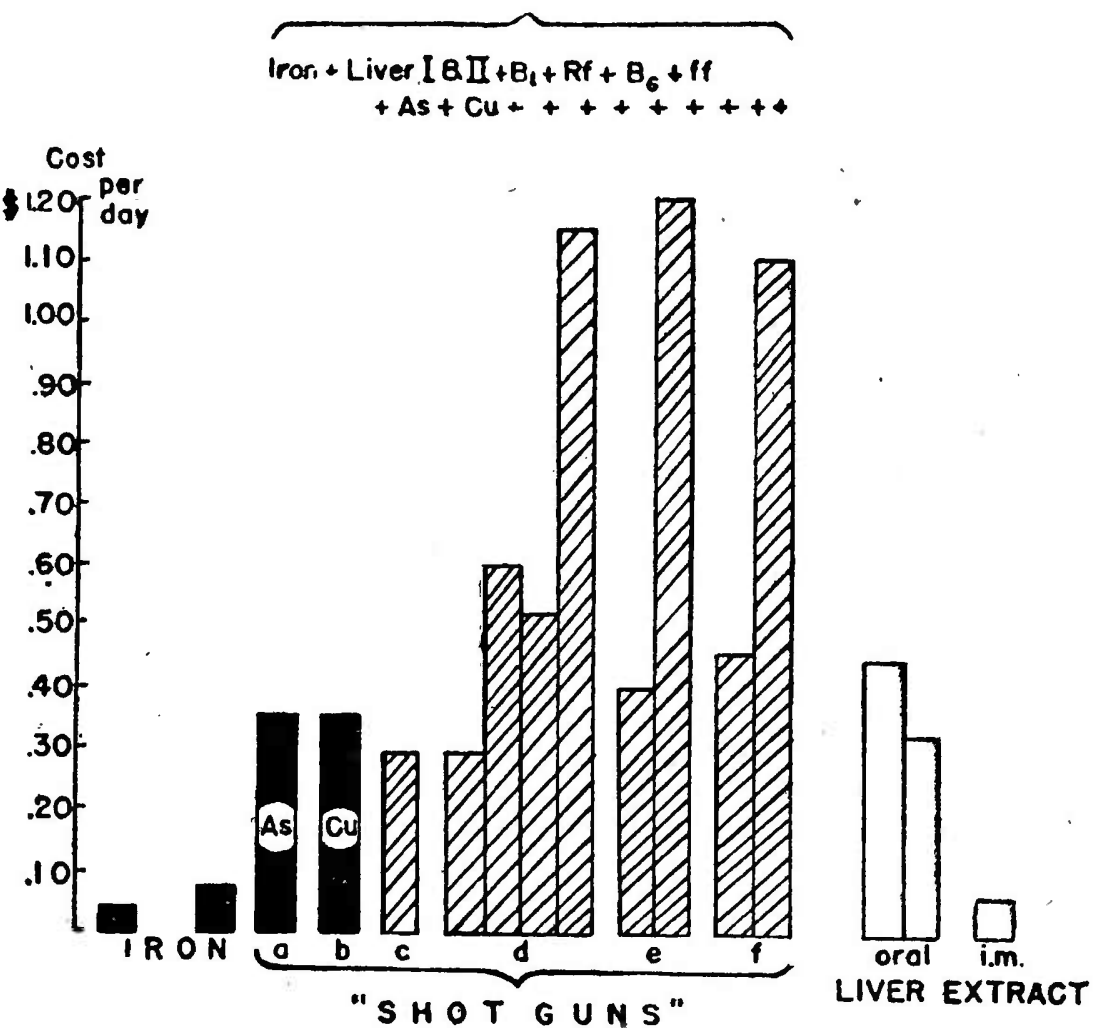

Fio. 52.-Comparison of the cost per day to the patient of adequate doses of iron given as simple ferrous sulphate (first black column), ferrous sulphate under a trade name (second black column) and in various iron preparations containing arsenic, copper, other minerals, liver extracts, gastric mucosa and vitamins. The cost of treatment in is also compared.

Portanto, um pequeno esforço por parte do médico aumentará o seu crédito perante o paciente como tambem aliviará o mesmo de uma despesa grande e relativamente desnecessária.

Basta administrar ferro sómente e o tratamento dietético adequado para suprirmos o. doente de outros fatôres que por ventura o caso necessite (diétas com proteínas animais, frutas, vegetais verdes, etc.). Orientada nesse sentido, a terapêutica das anemías tornar-se-á facil, econômica, mais rápida e proporcionará maior satisfação ao médico e doente. Si nas anemías hipocrômicas existe baixa de $\mathrm{Hb}$, si esta é uma das causas principais da queda do estado geral (hipooxidação dos tecidos, fraqueza, anorexia, etc.) e ainda mais si a $\mathrm{Hb}$ contem na 
sua molécula o ferro como um principal elemento, é justo que façamos o tratamento marcial, pois, os outros elementos da molécula de Hb ou já existem no organismo ou serão introduzidos pela alimentação mesmo não científicamente orientada.

Vejamos agora o tratamento das anemías hipocrômicas, ferroprivas, deixando de lado a discussão dos outros constituintes uteis à hematopoiése que, como dissemos, poderão ser incorporados à terapêutica mediante uma diéta bem orientada.

Ferro: Desde o tempo de Hipócrates são empregados os sais de ferro para o tratamento das anemías. A ferroterapía originou-se de uma prática antiga em que os doentes bebiam agua na qual tinha sido mergulhada uma espada e aí permanecia até oxidar-se. SyDENHAM (25) há 300 anos introduziu o ferro na prática médica para o tratamento da clorose da histería".

A terapêtutica pelo ferro foi desacreditada no periodo de 1890 a 1920 quando Bunge afirmou que sómente as fórmas orgânicas de ferro eram ativas.

Devemos posteriormente a Lichtenstein e Menlengracht (33) a ressurreição da terapêtica marcial sob a forma de ferro inorgânico, e a ABDERHALDEN (30) que tambem achou que o ferro inorgânico era eficaz sobre a hematopoiese.

Este metal foi considerado como fatôr importante na hematopoiése desde Menghini (30) que, em 1747 descobriu esse elemento no sangue.

Metabolismo do ferro: A molécula de $\mathrm{Hb}$ é formada de uma parte constituída por 4 núcleos pirrólicos com um átomo de ferro ligados com uma proteína - globina - Não quer isto dizer que o organismo sómente utilise o ferro para a formação da $\mathrm{Hb}$ pois 5 a $10 \%$ da ferro total existente no organismo entram na constituição de certos enzymas respiratórios e outras substâncias biológicamente atívas.

Absorção do ferro: A absorção do ferro se dá principalmente no duodêno e na primeira porção do intestino delgado. Segundo alguns autôres, dar-se-ía tambem no estômago. Ele é quasi que inteiramente escretado pelas fezes (35). Do intestino, onde ele é absorvido, é pela circulação portal e linfáticos levado ao fígado e ganglios linfáticos mesentéricos. Ele se acumúla no fígado e daí é cedido, à medida das necessidades. Parece provado que o baço é séde do reservatório sómente para o ferro proveniente da degradação da $\mathrm{H}$ b dos glóbulos vermelhos pois quando se administram compóstos de ferro à animais anêmicos, e com diétas desprovídas de ferro (36) verifica-se que em 1. lugar ha armasenamento desse metal no fígado e sómente mais tarde, quando a $\mathrm{Hb}$ volta aos seus valôres quasi normais é que se encontra siderose no baço. 
Quanto à forma sob a qual os compóstos de ferro são mais absorvidos parece de acordo os autôres que é sob a fórma de compóstos, ferrosos sendo os férricos menos absorvidos. Já Starkenstein dividindo os preparados de ferro em 5 grupos, afirmava que sómente os sais ferrosos eram ativos. O ferro para ser absorvido deve ser soluvel perfeitamente, facilmente ionisavel, e ultra filtravel, propriedades essas que apresentam os sais ferrosos.

Varios fatôres influem sobre a absorção do ferro: - vejamos os fatôres que auxilíam ou facilítam a absorção do ferro:-

Quasi todos os sais de ferro teem a sua absorção facilitada pelo meio ácido. - (48-49). Assim, alimentando-se (37) animais com regime de Sippy, alcalino, e com uma diéta rica em ferro, ha pequena absorção desse metal (controlada pela resposta reticulocitária) que é aumentada quando se passa ao regime ácido. Do mesmo modo a hipo ou a acloridría que geralmente acompanha ou é mesmo a causa de muitas anemías é um fatôr que prejudíca a ábsorção do ferro. Nesses casos a administração de ácido clorídrico melhora a absorção do metal. Admitem os autôres que o $\mathrm{ClH}$ do súco gástrico combina-se com o ferro formando cloreto ferroso facilitando a sua absorção, provavelmente pela solubilidade maior desse sal ferroso e ionisação maior.

Lintzel (38) mostrou que os sais férricos e não os ferrosos formam complexos com as proteinas e assucares de modo que no trato, gastro intestinal eles formariam estes mesmos complexos com o múco e proteínas não desintegradas tornando-se não absorviveis. Devemos notar entretanto que embora haja esta combinação existe no trato gastro intestinal uma baixa tensão de oxigênio e presença de muitas substâncias facilmente oxidaveis que tornariam os compóstos férricos em ferrosos facilitando assim a sua absorção.

A clorofila e os pigmentos biliares tambem favorecem a absorção do ferro.

Dos fatôres que prejudicam a absorção do ferro poderemos citar em primeiro lugar a relação $\mathrm{Ca} / \mathrm{P}$. ORTEN (30) em experiências realisadas em ratos mostrou que quando havia um excesso de fósforo na alimentação desses animais este combinava-se com o ferro precipitando-o e desse modo evitava a sua absorção. Bastava acrescentar a essa diéta com excesso de fósforo uma certa quantidade de carbonato de calcio de modo a tornar a relação $\mathrm{Ca} / \mathrm{P}$ normal, para que o ferro fôsse utilisado. Concluiu esse autôr que o importante para que se processe uma hematopoiese normal é a relação $\mathrm{Ca} / \mathrm{P}$ normal ou então a presença de algum fatôr na diéta que impeça a combinação do fósforo com o ferro. Deobald e ElvehJen (39) chamam a atenção sobre as grandes dóses de ferro para o tratamento das anemías podendo nestes casos haver uma perturbação na utilisação do fósforo.

Outro fatôr que inflúe sobre a absorção do ferro é a deficiência da vitamina $\mathrm{A}$, mas neste caso parece provavel que a causa primária 
é o estado infecioso que geralmente acompanha esta avitaminose A que impede a absorção.

Fatôr importante tambem que inflúe sobre a absorção é a dóse empregada para o tratamento das anêmias. Do ferro ingerído, "mais ou menos, 5 a $35 \%$ é utilisado para a produção de hemoglobina sendo esta porcentagem de utilisação tanto maior quanto menor a dosagem utilisada. Esta dosagem mínima tem um limíte em que a absorção é maxima. Infelizmente não podemos saber qual seja, devido á diferente sucetibilidade individual.

Numa série de conferências sobre a terapêutica das anemías realisada pelos membros do Departamento de Farmacologia e Medicina de Cornell University Medical College and New York Hospital (42-4344-45), mostrou-se que, por exemplo, quando se administrava 108 mmgrs. de ferro por dia sob a fórma de gluconato ferroso a utilisação era de $37 \%$ mas quando a dóse era duplicada a utiliśação passou a $17 \%$, portanto menos que a metade, fáto esse que confirma o que acabamos de dizer.

Alem da maior porcentagem de utilisação varias outras vantagens apresentam as dóses menores, principalmente:

1) Economía do tratamento.

2) Com as pequenas dóses; após as refeições, evita-se em grande parte a gastrite e as perturbações intestinais (vomitos, diarréas) que se verificam com as grandes dóses o que torna depois impossivel a continuação do tratamento.

Costuma-se objetar às pequenas dóses dizendo que produzem constipação. Ora, com pequenas dóses usadas por nós (no maximo 1,5 grs. de ferro reduzido pelo hidrogênio para os adultos e 0,75 para as crianças) e que será assunto de uma nossa proxima publicação, sómente em pequenissima porcentagem verificamos prisão de ventre que entretanto, dura 2 a 3 dias sómente, voltando, o intestino ao seu ritmo normal com a continuação do tratamento. Alem disso deve-se notar que a sucetibilidade individual varía muito de modo que esse inconveniente é facilmente afastado procurando-se uma dóse ótima. Com as dóses altas dificilmente pode-se remediar o inconveniente da diarréa e convencer o paciente para a continuação do tratamento.

Aconselha-se começar com dóses menores e subir gradativamente até a dóse que se deseja.

Do ferro absorvido uma parte é utilisada para a formação da hemoglobina quando necessario e o restante ou pelo menos, uma grande parte é armasenada no fígado, baço, rins e em todas as células do organísmo. A hemoglobina dos músculos (miohemoglobina) e o ferro das células dos tecidos não são utilisados para a formação da 
hemoglobina quando o organismo necessita, qualquer que seja o gráo de anemía.

Provavelmente sómente o ferro do fígado, baço e medúla óssea são aproveitados para esse fim.

Como sabemos, constantemente em nosso organismo ha destruição de glóbulos vermelhos principalmente pelo S. R. E. do baço e fígado e o ferro da Hemoglobina é novamente aproveitado havendo provavelmente uma pequena perda que é eliminada através do intestino e dos rins, advindo daí a necessidạde de sua ingestão diária para suprir as necessidades orgânicas principalmente quando se trata de organismo em crescimento ou de mulheres (devido ao período menstrual).

Avalia-se mais ou menos em 10 a 80 mmgrs a quantidade diária de ferro necessaria para o organismo. Segundo HeAth as mulheres necessitam 4 vezes mais ferro que os homens. Para as crianças avalia-se em 0,76 mmgrs por quilo de peso corporal.

- Reproduzinos em seguida o esquema muito ilustrativo do metabolismo do ferro retirado do livro de Wintrobe:

Ferro ingerido $\longrightarrow$ Estômago (ionisado ou dissociado pelo $\mathrm{ClH}$ livre)

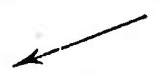

Intestino delgado (Alcalino. $\mathrm{O}$ ferro preparado para absorção sendo reduzido $\downarrow \quad$ ao estado ferroso)

Ferro absorvido do trato gastro intestinal<smiles>[3H][V]</smiles>

Depósitos (fígado, baço, etc.)

Ferro sanguineo de transporte (ferro do plasma)

$\uparrow$

Ferro dos glóbulos vermelhos destruidos

- (fisiológico ou patológico)

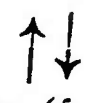

Excreção

a) Urina: pequena quantidade

b) Colon (ou diretamente ou através das vias biliares?)

(c. Hemorragia)

A medula óssea para a síntese da $\mathrm{Hb}$ e aos tecidos para as enzymas respiratorias

Instituido o tratamento marcial o resultado terapêutico é controlado pelo aumento do teôr hemoglobínico e pela resposta reticulócitária que é tanto maior quanto mais baixa fôr a taxa de hemoglobina inicial, isto é, a resposta reticulocitária está na rasão inversa da taxa de hemoglobina inicial. O máximo de resposta reticulocitária que se obtem com um tratamento adequado pelo ferro verifica-se do $4 .^{\circ}$ ao décimo dia após iniciado o tratamento sendo que depois de atingir o 
máximo vai declinando a porcentagem de reticulocítos à medida que sobe o teôr hemoglobínico.

Considera-se ótimo tratamento marcial quando a hemoglobina subir durante as primeiras semanas em média, 0,2 a 0,3 grs. por $100 \mathrm{cc}$ de sangue por dia (ou 1,4 a 2,1\%).

Dos compóstos de ferro geralmente usados para o tratamento das anemías trataremos do sulfato ferroso, citrato de ferro amoniacal e ferro redusido pelo hidrogênio.

Sulfato ferroso: Muito usado pelos autôres americanos e atualmente entre nós. E' uma forma sob a qual o ferro é facilmente absorvido e com a conveniência de que são usadas dóses pequenas podendo-se dar 0,6 a 1,2 grs por dia em tabletes ou em drágeas, (para evitar a sua oxidação muito facil). A sua oxidação produz o sal férrico cuja ação é menor por ser menos absorvivel. Com a dosagem indicada de sulfato ferroso obtem-se uma ótima resposta reticulocitária e uma melhora da anemía, rápida.

Citrato de ferro amoniacal: Os autôres são partidarios, de um modo geral, a dóses altas desse produto chegando Wintrobe a aconselhar 6 a 8 gramas diárias. Infelismente não temos experiências com este' sal.

Ferro redusido pelo hidrogênio: E' o que se acha mais difundido entre nós. Quanto à sua dosagem existem autôres partidários das grandes e outros partidários das pequenas dóses. Segundo WintROBE seriam necessarias para um bom tratamento 4 a 6 gramas de ferro redusido pelo hidrogênio, diariamente, outros autôres aconselham, no mínimo 3 grammas diárias (50). Entretanto, segundo nossa experiência bastäm sómente 1,5 grs para se obter uma ótima resposta reticulocitária e uma volta rapida da hemoglobina ao seu nivel normal. Com esta doságem obtivemos casos com 3\% de regeneração hemoglobínica média diária tratando-se de casos com 20 a $30 \%$ de hemoglobina inicial.

Sería de conveniência a administração de ácido clorídrico juntamente com a terapêutica marcial? Como dissémos, frequentemente a hipo ou acloridría acompanham esses estados anêmicos e portanto o "seu emprego é rasoavel. Segundo nossa opinião e como temos observado, dever-se-ia empregar o ácido clorídrico sómente quando se tratásse de casos graves de anemía onde provavelmente já existe acentuada hipocloridría ou mesmo acloridría. Nos outros casos, as pequenas dóses, devido à propria irritação da mucosa gástrica pelo ferro, excitariam a mucosa para a produção do ácido clorídrico que por ventura estivesse deficiente.

O ácido clorídrico produzido não só facilíta a absorção do ferro como tambem melhora a digestão fazendo com que outros produtos indispensaveis à hematopoiese e introduzidos com a alimentação sejam absorvidos. 
Questão importante é a administração do ferro por via parenteral. Por essa via de administração a absorção do ferro é cerca de 30 veses mais ativa do que a administração por via oral de modo que à primeira vista sería de conveniência o uso dessa via.

Heath, Strauss e Castle (46-47) verificaram que 1.000 mmgrs. de ferro sob a forma de citrato de ferro amoniacal dado por boca eram equivalentes a $32 \mathrm{mmgrs}$. quando por via parenteral.

Esta via entrętanto apresenta certos inconvenientes:

1) As injeções são muito dolorosas, irritantes podendo até provocar necrose do tecido.

2) E um tratamento incômodo devido à necessidade de injeções.

3) Póde produzir sintômas tóxicos quando injetada a dóse necessaria (palpitações, sensação do calôr, náusea, vômitos, taquicardía, pressão precordial, etc., etc.).

4) A dóse terapêutica ótima è muito proxima da dóse tóxica.

Aconselha-se esta via apenas para os casos em que houver hipersensibilidade do indivíduo mesmo às pequenas dóses dadas por via oral, ocorrencia essa raríssima.

A associação do estráto hepático ao ferro só é indicada naqueles casos em que houver deficiência de F. M. E. ao lado da deficiência, de hemoglobina, isto é, naqueles de anemía macrocítica hipocrômica.

\section{BIBLIOGRAFIA}

1 - Воусотт, A. E. - Pathology of the blood. Chapter II in Tex book of General Pathology edited by M. S. Pembrey and J. Ritchie, Longmans Green and. Co. New York, $1913 \mathrm{em}$ Castle and Minot.

2 - Witrs, L. J. - The pathology and treatment of anaemia. Lancet, 1932, I, 495, 540, 601, 653 em Castle e Minot.

3 - Neumann, E. - Zembralbl f. d. med. Wiss. 1882, 321 em Varela.

4 - Ponfik, E. - Virch Arch., 56, 536 em Varela.

5 - Ferrata, A. - Le emopatie; Società Editrice Libraria Milano 1932 - 2. ${ }^{\mathrm{a}}$ edição. Vol. I, parte I.

6 - Ferrata. A. - Le emopatie Societa Editrice Libraria Milano 1933 $2 .^{a}$ ediçã̃o. Vol. I, parte II.

7 - NAEGELI, O. - Tratado de Hematologia clinica Editorial Labor S. A. 1934. Tradução da $5 .^{2}$ edição alemã.

8 - Sabin; DoAn; Cunninghan - em Downey, H. - Handbook of Hematology. New York, Paul B. Hoeber, Inc, 1938.

9 - Varela, M. E. - Hematologia Clinica. El Ateneo, Buenos Ayres 1941.

10 - Murphy, W. P. - Anemia in Practice - Pernicious Anemia. W. B. Saunders Company, 1939 Philadelphia and London.

11 - Mattar, E.; Almeida, S. S.; Russo, E. M.; Jannini, P.; Chapchap, A. - Estudos de Hematologia Infantil. (Premio Alvarenga 1941). No prelo.

12 - Piccaluga, F. e Herlitzha, L. - Las anemias por carencia nutritiva y su tratamiento, con especial referencia a la hepatoterapia. Revista Medica Latino Americana - XXVI - 303 - Dez. 1940.

13 - Introzzi, Fieschi - La biopsia del midollo osseo - 1939.

14 - Frost, D. V. Elvehjen, C. A. and Hart, E. B. - Iron utilization in Dogs on Milk Diets. Journ. Nutr. 19,311, 1940 em Wintrobe 
15 - Elvehjen and Shermann - J. Biol. Chem. 98 - 309, 1932 em Mc Collum.

16 - Waltner and Waltner - Klin. Wchnsch., 8, 313, 1929 em Mc Collum.

17 - Barron and Barron - Proc. Soc. Exper. Biol. \& Med. 35, 407, 1936 em Mc Collum.

18 - Frost, D. V.; Elvehjen, C. A. and Hart, E. B. - Study of Need for Cobalt in Dogs on Milk Diets. Journ. Nutr. 21, 93, 1941.

19 - Orten - Am. J. Physiol. 114, 414, 1936 em Mc Collum.

20 - Orten - Amino acids and Hemoglobin Production in Anemia. Jour. Exper. Med. 71, 569, 1940 em Wintrobe.

21 - Mettier, S. R., Minot G. R. and Townsend W. C. - Scurvy in adults; Especially the effect of good rich in vitamin $\mathrm{C}$ on blood formation. Jour. Am. Med. Assoc. vol. 45, 1089, 1930.

22 - Crandon J. H., Lund C. C. and Dill D. B. - Experimental Human Scurvy New England Jour. Med. 353, 1940 em Wintrobe.

23 - Lozner, E. L. - Studies on Hemoglobin Regeneration in Patients with Vitamin C deficiency, New England Jour. Med. 224, 265, 1941 em Wintrobe.

24 - Street, H. R. ; Cowgill, G. R. e Zimmermann, H. M. - Some Observations of Vitamin $B_{6}$ Deficiency in the Dog. J. Nutr. 21, 275, 1941.

25 - Wintrobe, M. M. - Clinical Hematology. Lea \& Febiger - Phila-. delphia - 1942 .

26 - BARKer, W. H. and Miller, D. K. - Clinical Observations on the Whipple liver Fraction (Secondary anemia fraction), Am. Jour. Med. Sc. 195, 3, 792, 287 March 1938.

27 - Russo, E. M., Jannini, P. - As plaquetas e os reticulocitos no sangue periferico do recemnascido e do lactente normais. Pediatria Pratica XII - Maio-Junho 1941 - Fasciculo III.

28 - IsaAcs; R. and Friedman, A. - Standards for Maximum Reticulocyte Percentage After Intramuscular Liver Therapy in Pernicious Anemia. Am. Jour. Med. Sc. 196, 718, 1938.

29 - Whitby, L. E. H. and Britton, C. J. C. - Disorders of the Blood. J \& A Churchill - London Third Edition.

30 - Mc Collum, E. V.; Orent, E.; Keilles and Henry G. Day - The Newer Knowledge of nutrition. Fifth edition, Rewritten. The Macmillan Company - New York 1940.

31 - Israels, M. C. G. and Wilkinson, J. F. - Achrestic Anemia: Quart. Jour. Med. 5, 69, 1936. Ibid 9, 163, 1940 em Wintrobe.

32 - Fonts, P. J.; Helmer, O. M. and Lepkovsky, S. - Nutritional Microcytic Hypochromic Anemia in Dogs Cured With Crystalline. Factor I. Am. Jour. Med. Sc. 199, 163, 1940.

33 - HADEN, R. L. - Historical Aspectos of Iron Therapy in Anemia. Jour. Áme. Med. Assoc. 111, 1059, 1938.

34 - Abderhalden - Ztschr. f. Biol. 39, 193, 483, 1900 em Mc Collum.

35 - BARR - Modern Medical Therapy in General Practice. Vol. I. The William \& Williams Company, 1940 Baltimore.

36 - ScHMIDT - Der Einfluss Eisenarmer und Eisenreicher Nahrung auf Blut und Korper Fischer, Jena 1928.

37 - Kellog, F. and Mettier, S. R. - Effect of Alkaline Therapy for Peptic Ulcer on Utilization of Dietary Iron in the Regeneration of Hemoglobin. Arch. Int. Med. 58, 278, 1936.

38 - Lintzel - Ergebn d. Physiol. 31, 844, 131 em Mc Collum.

39 - Deobald and Elven Jen - Am; Jour. Physiol. 11, 118, 1935 em Mc Collum.

40 - Goldhamer, M. S. - Macrocytic Anemia in Cancer of the Stomach, apparently due to Lack of Intrinsec Factor - Amer. Jour. Med. Sc. 195, 790, Janeiro 1938.

41 - Schiff, L., Rich, M. L. Simon, S. D. - The "Hematopoietic Principle" in the Diseased Human Liver: Am. Jour. Med. Sc. 196, 3, 798, 313, Set. 1938. 
42 - Conferences on Therapy: Therapy of Blood Disorders VI - Pernicious and Other Macrocytic Anemia. Jour. Am. Med. Assoc. 115 - 1 July $6-39-1940$.

43 - Idem I - Iron Therapy: $114-22$ - June I - 2.207 - 1940.

44 - Idem II - The use of Iron and Other Metals. 114, 23, June 8, $2.301-1940$.

45 - Idem V - Microcytic Anemia 114, 26, June 29, 2.544, 1940.

46 - Heath, C. W. and Patek, A. J. - The Anemia of Iron Deficiency, Medicine, 16, 267, 1937 (Bibliography) em Wintrobe.

47 - Heath, C. W., Strauss, M. B. and Castle, W. B. - Quantitative Aspects of Iron Deficiency in Hypochromic Anemia. Jour. Clin. Invest. $11,1.293,1932$ em Wintrobe.

48 - Cantarow, A. and Trumper, M. -- Clinical Biochemistry. W. B. Saunders Company. Philadelphia and London, 1939.

49 - PovoA, H. - Sangue e Metabolismo. Editora Scientifica - Rio de Janeiro, 1940.

50 - Corrêa, J. B.; Cruz, L. e Barros Netto, J. B. . M. de - O ferro reduzido no tratamento das anemias secundarias. Rev. Assoc. Paul. Med. 1(1):40-48, Jan. 1932

51 - Oris, J. - Baço Myeloide e Megacariocito do "Genathrà". Anais da Fac. Med. da Univ. S. Paulo. Vol. 17. Tomo I, pg. 139, 1941.

\section{Dr. \\ Mozart Tavares de Lima Filho}

Diretor Clinico do Sanatorio Ebenezer

TRATAMENTO DA TUBERCULOSE

Vila Capivari

Campos de Jordao

\section{Gengivas doentes?}

\section{"PYORRHON"}

Dá saúde ás gengivas, porque é remédio e... é dentifricio 